\title{
Geotechnology as a Planning Tool in the Determination of Forest Extraction Costs
}

\author{
Francisco de Assis Costa Ferreira ${ }^{1}$ (D) Luis Carlos de Freitas ${ }^{1}$ (D), \\ Elton da Silva Leite ${ }^{2}$ (D), Ana Paula da Silva Barros ${ }^{1}$ \\ ${ }^{1}$ Universidade Estadual do Sudoeste da Bahia (Uesb), Vitória da Conquista, BA, Brasil \\ ${ }^{2}$ Universidade Federal do Recôncavo da Bahia (UFRB), Cruz das Almas, BA, Brasil
}

\begin{abstract}
The objective of this work was to use the geotechnology study as a planning tool in determining the costs of forest extraction. The research was carried out in areas of the Forest Company that operates in the southern region of Bahia, Brazil. The work was developed in two stages, the first corresponding to the determination of production costs of the forwarder and the second in the machine's productivity, taking as parameter the project area and the distance of extraction. The proposed methodology allowed to estimate with precision the distance of extraction, being this variable of great influence in the costs of forest extraction. The evaluated project presented 256.30 hectares of eucalyptus plantation, divided into 10 plots, with an extraction mean distance of 200 meters. According to the study, it would require the value of US\$102,575.33 for the extraction of the wood from the project evaluated.
\end{abstract}

Keywords: forwarder, forestry projects, geoprocessing. 


\section{INTRODUCTION AND OBJECTIVES}

The forest harvesting is one of the steps of the productive chain in planted forests. This step demands high financial funds, representing over $50 \%$ of a forest enterprises expenses (Machado et al., 2014).

Currently, the mechanized methods are highly used in the large forest corporations, especially for its productivity and cost reduction in production process. The mechanization has contributed to the efficiency of the forest harvesting process, also increasing productivity, reducing costs and avoiding accidents, while facilitated the operations management process (Spinelli, 2009).

Among the timber harvesting systems, the cutto-length logging system is highlighted in Brazil. In this system, usually using the Harvester method, the trees are put down and processed in the interior of the tank at a maximum of six meters length. On the other hand, in extraction, the forwarder method is used.

The forest extraction is put down to the wood movement from the cut place to the log deck. It is also influenced by several variables of a technical and operational nature, among them the extraction distance and the slope of the land stand out (Leite et al., 2014). Leite et al. (2014) mention that the higher the distance of extraction, the smaller the forwarder's productivity.

In order to determine the costs of forest extraction, it is necessary to gather information on the productivity and on costs of the equipment, as well as data of a technical/operational nature of the project, such as the area and distance of extraction of each of the battalions, volume of lumber etc.

The productivity of the equipment can be obtained through the study of times and movements, which aims to identify and quantify the time required for the activities that make up the operating cycles of the harvesting equipment, usually by the timing method (Moreira et al., 2004; Minette et al., 2004).

The use of geotechnology can help in determining the area to be harvested, optimizing routes for removal of the timber of the battalion, determining the density of roads and, mainly, the average distance of the transportation of timbers, being a difficult parameter of being measured in other ways. With the help of this tool, it becomes possible to manage the technical information in a way to guide the planning in the search for information regarding the cost of forest extraction depending on the distance of the transportation of timbers.

Considering this scenario, this work aimed at using geotechnology as a subsidy to the planning in determining the costs of forest extraction, at different distances of timbers transportation.

\section{MATERIALS AND METHODS}

\subsection{Characterization of the study area}

The study was carried out in areas of a forestry company located in the far south state of Bahia. The region has a climate of type Af (humid tropical), with precipitation and average temperature of $1,250 \mathrm{~mm}$ and $24^{\circ} \mathrm{C}$ respectively (Koeppen, 1948). According to Novaes \& São José (1992), the natural vegetable cover is the dense ombrophilous forest, under the dominion the Atlantic Forest. The land of this region is considered very poor, being acrisols and latosols more frequently found (Embrapa, 2006)

The evaluations were carried out in flat areas (average slope of 5\%), with hybrid clones of Eucalyptus Grandis and Urophylla, in plantations coming from second rotation of 7 years, spacing of $2.40 \mathrm{~m}$ between plants by $5.00 \mathrm{~m}$ between lines, with average individual volume per tree without bark (VMIsc) of $0.30 \mathrm{~m}^{3}$. The harvesting system adopted is the cut-to-length loggings being extracted with approximate length of $6.20 \mathrm{~m}$, from beams formed by harvester.

\subsection{Characterization of the rated equipment}

The equipment was evaluated in the daytime, from 6 a.m. to 6 p.m., from November to December 2016. Five forwarders Ponsse ${ }^{ø}$ were used, model Elephant, equipped with six-cylinder motor Mercedes-Benz OM 906 LA EU Stage IIIA with 275 HP $(205 \mathrm{~kW})$ Power, eight-wheel drive $(8 \times 8)$. The machine with normal weight totalizes $21,800 \mathrm{~kg}$, its crane has a range of approximately $7.6 \mathrm{~m}$, model $\mathrm{K} 100+\mathrm{m} / \mathrm{s}$, being the claw engaged at its end with capacity of $0.36 \mathrm{~m}^{2}$ (Ponsse, 2014). The crane of this equipment has the capacity to raise approximately $1,500 \mathrm{~kg}$ when loading and unloading. 
The load box has a variable length of $4.5 \mathrm{~m}$ to $6.10 \mathrm{~m}$, its transverse section varies from $5.20 \mathrm{~m}^{2}$ to $6.25 \mathrm{~m}^{2}$ (Ponsse, 2014). This equipment has a load capacity of $18 \mathrm{t}$, being recommended to operate in areas of up to $27^{\circ}$ front tilt and $10^{\circ}$ lateral tilt.

\subsection{Forwarder productivity}

Operating cycles were quantified from $50 \mathrm{~m}$ to $500 \mathrm{~m}$ away from transporting timbers. Each operating cycle was composed by the following steps (Figure 1): unladen displacement (when the machine, empty, has moved from the formation site of the wood pile until the start of loading); loading (moment in which the machine stopped dislocating unloaded and proceeded to collect the wooden beams arranged in the battalion until completing the cargo box; being this the moment when the change of beams was computed); displacement with load (moment when the machine started the displacement with the full load box until the arrival at the place of formation of the wood stack); and unloading (when the machine has started to unload the log beams contained in the load box for the wood stack).
For the determination of the time spent in carrying out the operational cycle at each extraction distance evaluated ( $50 \mathrm{~m}$ to $500 \mathrm{~m}$ ), a stopwatch of the Vollo brand, model VL 1809, was used. The distance traveled by the forwarder was measured by a hypsometer of the brand Laser Technology ${ }^{\circledast}$, Model TruPulse 200 B.

For determining the minimum number of cycles that would meet a maximum permissible sampling error of 5\%, with $95 \%$ probability, the methodology proposed by Conaw (1977) was used, according to Equation 1, also employed in the work of Lopes et al. (2011).

$$
\mathrm{n} \geq \frac{\mathrm{T}^{2} * C V^{2}}{\mathrm{E}^{2}}
$$

$\mathrm{n}$ : minimum number of cycles required; t: value of $\mathrm{T}$, for the desired level of probability and (n-1) degrees of freedom; CV: coefficient variation (\%); E: permissible sampling error at $95 \%$ probability.

The productivity of forwarder was determined in cubic meters of shell-free wood for hours effectively worked $\left(\mathrm{m}^{3} \mathrm{~h}^{-1}\right)$, according to Equation 2. It was considered the forwarder load capacity of $17.2 \mathrm{~m}^{3}$ of wood without shell, value obtained from the company.
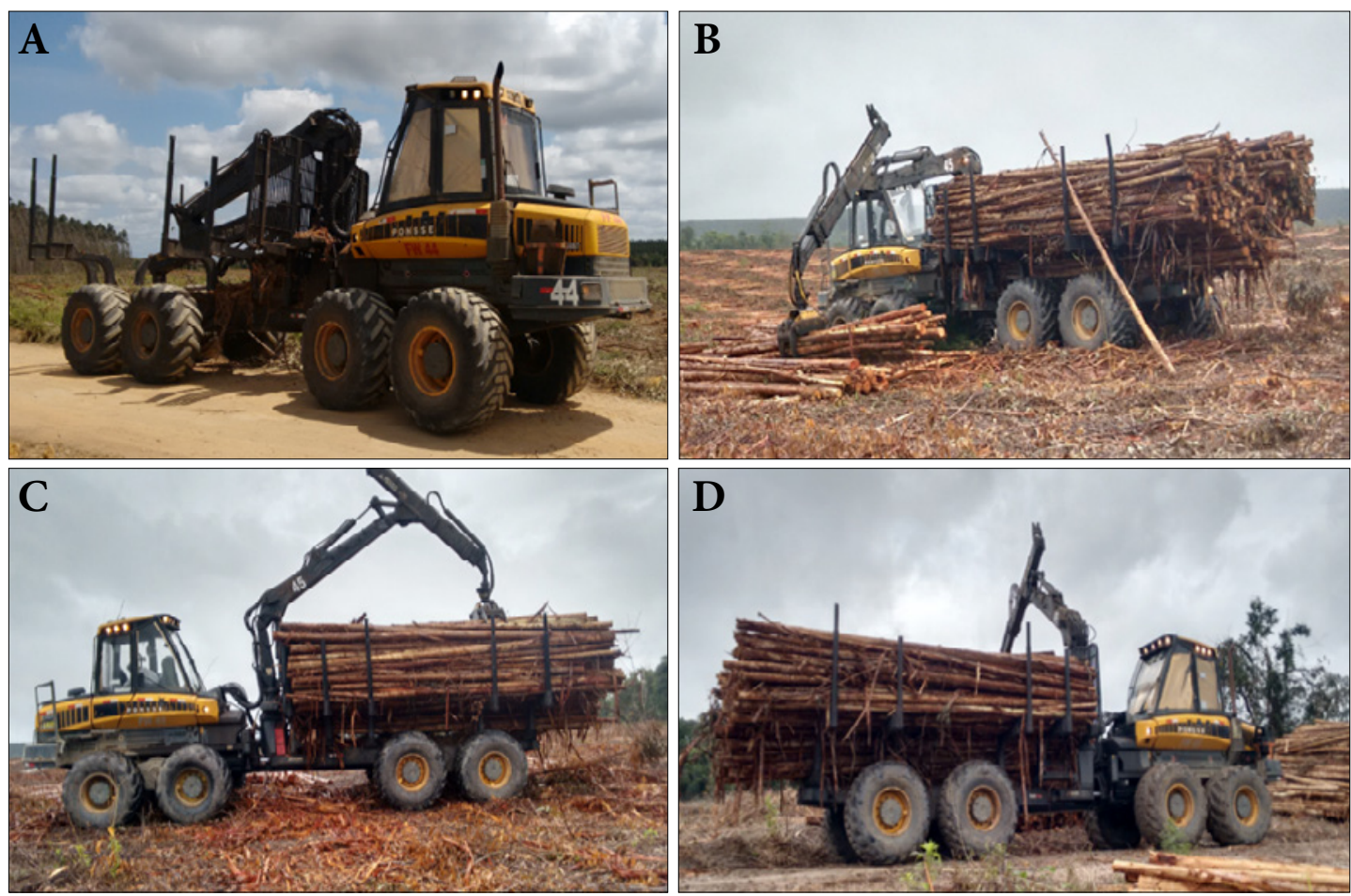

Figure 1. Stages of the forwarder operating cycle. A: unladen displacement; B: loading; C: load displacement; D: unloading. 


$$
\mathrm{P}=\frac{17,2}{\mathrm{~T}}
$$

P: productivity $\left(\mathrm{m}^{3} \cdot \mathrm{h}^{-1}\right)$; T: time spent (hours) to run the operational cycle.

Having the productivity information of each operational cycle, a linear regression analysis was carried out, with the dependent variable being the productivity $\left(\mathrm{m}^{3} \cdot \mathrm{h}^{-1}\right)$ and the independent variable the distance of timbers transportation (m).

\subsection{Operating costs}

Operating costs (fixed and variable) were expressed in dollars per effective hour of work (US\$. $\left.h^{-1}\right)$, according to the accounting method, which uses actual and estimated data. For the estimated values, the methodology proposed by Silva et al. (2014) and American Society of Agricultural Engineers (Asae, 2001) was used, as shown in Equations 3 to 12 (Table 1).

The costs of operators and machines transportation for the evaluated project area, as well as the others used to compute the values (Table 1), were made available by the company. The exchange rate of the dollar was used equal to $\mathrm{R} \$ 3.1244$, based on the quotation held on February $9^{\text {th }}, 2017$.

\subsection{Determining the forwarder production costs}

To estimate the forwarder's cost of extraction, the operational costs of the equipment have been determined $\left(\mathrm{US} \$ \mathrm{~h}^{-1}\right)$ as well as the productivity, depending on the distance of transportation of timbers $\left(\mathrm{m}^{3} \cdot \mathrm{h}^{-1}\right)$, as per Equation 13.

Table 1. Equations for determining the forwarder operating cost.

\section{Source}

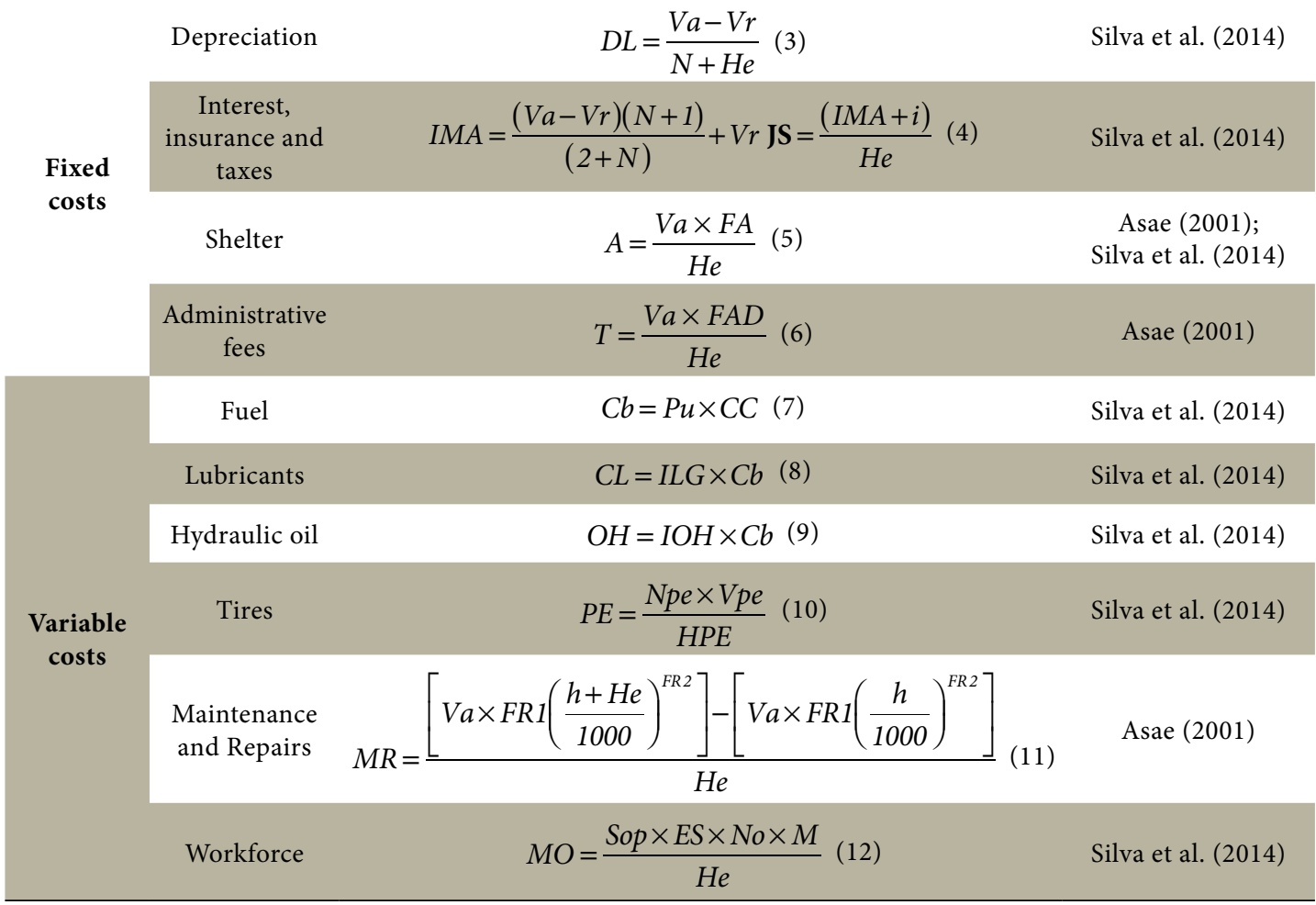

Va: machine purchase value (US\$ 388,889.00); Vr: residual value, 10\% Va (US\$); He: effective hours of annual use (4.021 h); N: life span (6 years); IMA: annual average investment; i: interest rate (10\%); FA: housing factor (0.75\%); FAD: administrative factor (2\%); Pu: fuel price (US\$ $\left.0.66 \mathrm{~L}^{-1}\right)$; CC: fuel consumption (16 L.h-1); ILG: lubricant index (5.5\%); IOH: hydraulic oil index (8.5\%); Vpe: tire price (US\$ 3,520.68); HPE: tire Lifespan (10,000 h); Npe: number of tires (8); FR1: factor 1 (0.003); FR2: factor 2 (2); h: time you want to calculate (h); Sop: Monthly salary of the operator (US\$ 896.17); No: number of operators (3); ES: charges (2.00); M: months in the year (12); Cb: fuel cost; CL: lubricants cost; $\mathrm{OH}$ : hydraulic oil cost; PE: tires cost; MR: maintenance and repairs cost; MO: labor cost. 


$$
\mathrm{CP}=\frac{\mathrm{CO}}{\mathrm{PFB}}
$$

CP: forwarder's production cost in the timber transportation (US\$. $\left.\mathrm{m}^{-3}\right)$; CO: operating cost (US\$. $\left.\mathrm{h}^{-1}\right)$; PFB: productivity depending on the distance of timbers transportation $\left(\mathrm{m}^{3} \cdot \mathrm{h}^{-1}\right)$.

\subsection{Determination of the average distance of timbers transportation: parameter for obtaining the extraction cost}

For determining the extraction average distance (EAD) of the plots, parallel semilines equidistant 30 meters were created with the command Create Vector grid contained in the free tool Hawthorne's Tools (Spatial Ecology, 2007). Following the planting sense, a condition used for the purpose of forwarder has a pass restriction on stumps.

In the plot where there are roads with stack formation available only on one side, the length of the semi-straight lines was divided in half, and in the plot with roads with stack formation available in both directions the length of the semi-straight lines was divided in four parts, due to forwarder to extract wood considering two senses of the plot (Figure 2). The average extraction distance was determined according to the Equation 14.

$$
\mathrm{EAD}=\frac{\sum x}{n}
$$

EAD: extraction average distance $(\mathrm{m})$; $\mathrm{x}$ : length of semi-straight lines (m); n: amount of semi-straight lines.

An estimative of the extraction cost of the forest project was calculated according to Equation 15 , and then the values were summed up, totaling the extraction cost of the project.

$$
\mathrm{CET}=(A * V M I * P H A) *\left(\frac{C O}{\text { Prod }}\right)
$$

CET: extraction cost of the battalion (US\$); A: area of the Army (hectare); VMI: individual average volume in shell $\left(\mathrm{m}^{3}\right)$; PHA: quantity of plants per hectare (unit); CO: forwarder operating cost (US\$. $\left.\mathrm{h}^{-1}\right)$; Prod: forwarder productivity depending on the average distance of timbers transportation $\left(\mathrm{m}^{3} \cdot \mathrm{h}^{-1}\right)$.

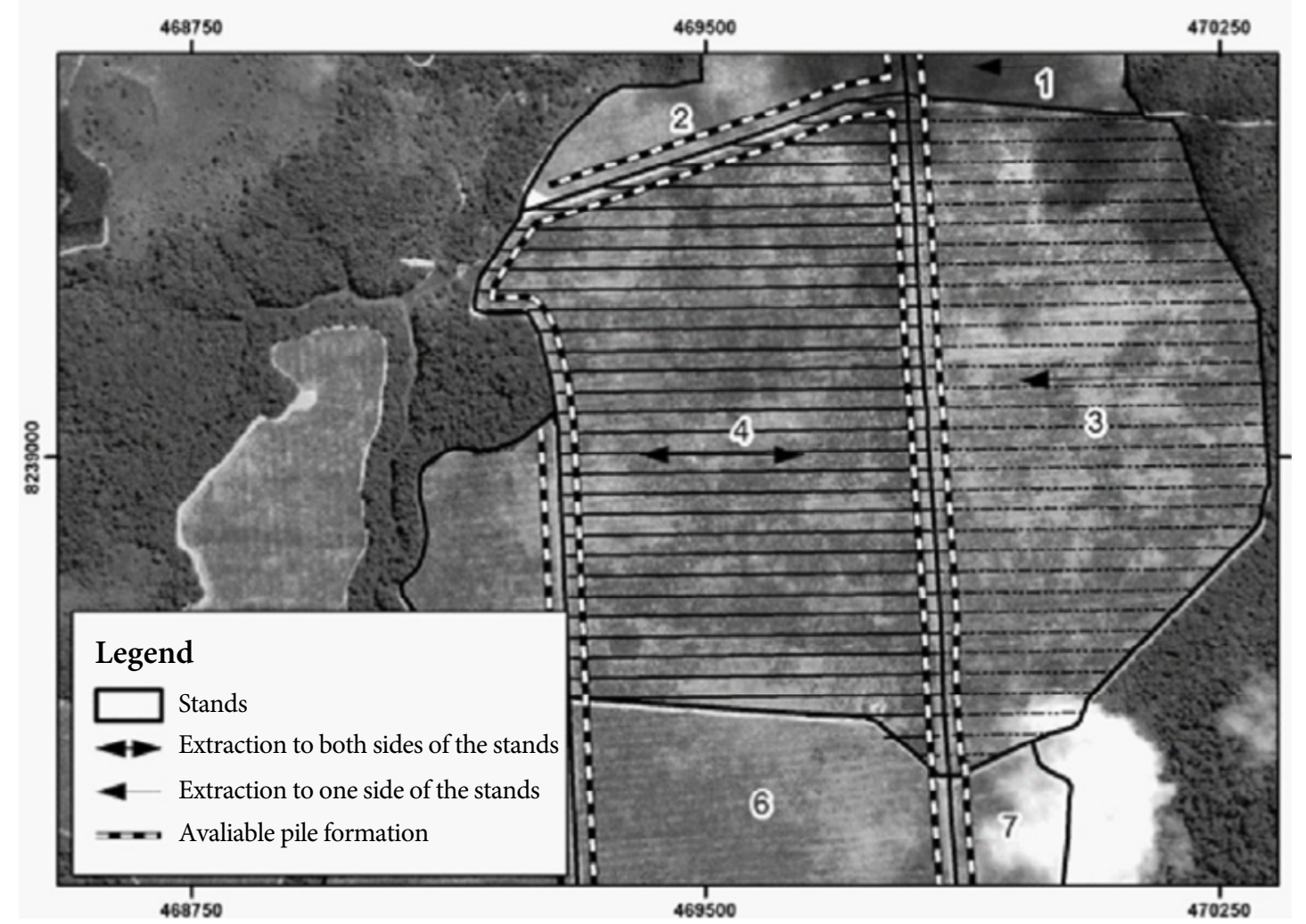

Figure 2. Methodology used. 


\subsection{Productivity modeling}

A modeling was carried out in order to estimate the volume of wood extracted per hour of work of the forwarder $\left(\mathrm{m}^{3} \cdot \mathrm{h}^{-1}\right)$ depending on the extraction distance $(\mathrm{m})$.

\section{RESULTS AND DISCUSSION}

\subsection{Forwarder productivity}

The methodology proposed by Conaw (1977) presented the need to evaluate 54 cycles; however, 100 operating cycles were quantified, totaling 31.1 hours of observation and $1,720 \mathrm{~m}^{3}$ of wood without shell extracted from the inside of the battalion to the edge of the road. The average productivity was $56.7 \mathrm{~m}^{3} \cdot \mathrm{h}^{-1}$ with an average distance of 200 meters.

As the distance of timbers transportation increases, there is greater time spent in the empty and loaded displacement, and consequently there is a decrease in the forwarder productivity (Malinovski et al., 2006). Minette et al. (2008) modeled the forwarder productivity and the self-charging agricultural tractor, depending on the distance traveled with the load. The authors realized that the productivity was strongly influenced by the distance of displacement.

The results of the study in question presented high productivity when compared to the work carried out by Leite et al. (2014). The estimated productivity showed up according to the operational conditions evaluated (flat areas, capacity to operate with full load, higher equipment load capacity and high productivity). Figure 3 shows the forwarder productivity modeling depending on the extraction distance.

The coefficient of determination $\left(\mathrm{R}^{2}\right)$ of the equation generated by the forwarder modeling evidences that $70 \%$ of the equipment productivity is explained by the distance of timbers transportation, the remainder can be attributed to various causes, such as passages on stumps, difficulty in accessing the extension to perform unloading, reducing the pace of work depending on the physical and mental fatigue of the operators experience, among other factors that can influence the equipment productivity.

Mazão et al. (2017) report as important measures to improve productivity in the forest extraction process with forwarder, in addition to the extraction distance, operator training and the best range of hydraulic cranes. Malinovski et al. (2006), studying the main factors that can influence the increase in forwarders productivity, found that the productivity of this type of equipment is affected by the assortment of wood, machine traffic and total occupation of its useful area of load of the claw, according to the dimensions of the assortment.

\subsection{Operating costs}

The operational cost of forwarder Ponsse, Elephant model, was US\$ 97.63 per hour effectively worked,

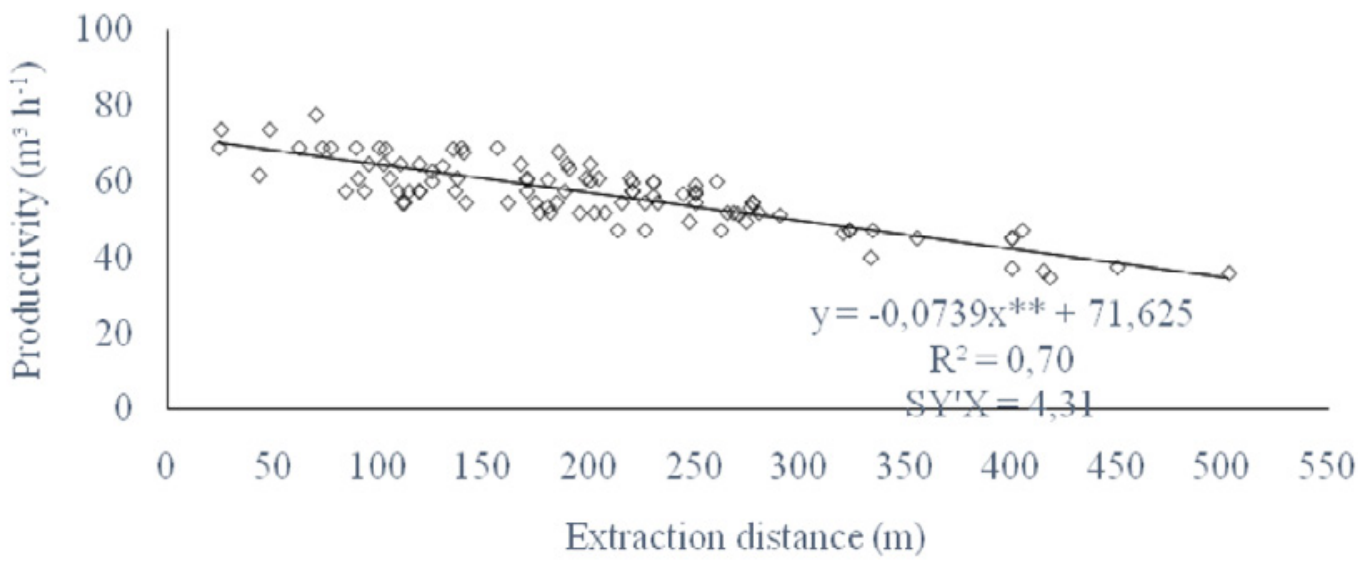

Figure 3. Forwarder productivity modeling. ${ }^{* *}$ : $\left(0.01>\right.$ probability); $\mathrm{R}^{2}$ : coefficient of determination (\%); SY'X: residual standard error $\left(\mathrm{m}^{3} \cdot \mathrm{h}^{-1}\right)$. 
considering interest rate of $10 \%$ per year, with operating efficiency of $81.4 \%$ and machine and mechanical availability of $84.6 \%$. In total, $23.77 \%$ (US\$ $23.21 \mathrm{~h}^{-1}$ ) were fixed costs and $76.23 \%$ (US\$ $74.42 \mathrm{~h}^{-1}$ ) were related to variable costs. The operational cost values are shown in Figure 4.

The results in Figure 4 demonstrated that the highest operational cost of the equipment was maintenance and repairs (38.5\%), followed by labor (16.04\%) and depreciation (14.50\%).

As the machines were approximately half a lifetime, the maintenance and repairs costs were more constant, depending on the greater amount of corrective maintenance. This result corroborates the study of Simões \& Fenner (2010), who concluded that, from a certain number of hours of use, repairs and maintenance costs become superior to the other items that make up the operating costs.

The measured values in this work are similar to that of the study carried out by Simões \& Fenner (2010), who have measured the cost of US $\$ 92,47 \mathrm{~h}^{-1}$ for a forwarder of the Valmet brand, model 890.2/WD, $21.84 \%$ corresponding to fixed costs and $78.16 \%$ to variable costs. Leite et al. (2014) estimated cost of US\$ $125.24 \mathrm{~h}^{-1}$, being $20.88 \%$ for fixed costs and $79.12 \%$ for variable costs. The $28.28 \%$ increase in operating costs estimated by Leite et al. (2014), when compared to this work, was due to the highest interest rate used by the authors (12\%), higher purchase value of the machine (US\$ 477,242.50), fuel price (US\$ $1.82 \mathrm{l}^{-1}$ ), among other factors.

According to the productivity modeling, the production cost of forwarder totalized US $\$ 1.72 \mathrm{~m}^{-3}$ for average distance of 200 meters, superior value to the estimated by Simões \& Fenner (2010) (US\$ $0.97 \mathrm{~m}^{3}$ ). This result can be attributed to higher productivity of the rated equipment and less extraction distance. Leite et al. (2014) estimated a production cost of US\$ $2.96 \mathrm{~m}^{3}$ for average distance of 200 meters in flat areas. This can be associated to higher operating costs and lower equipment productivity. Figure 5 presents the influence of the extraction distance in productivity and in the production cost of the forwarder.

Figure 5 shows that the production cost is directly related to the extraction average distance and reversed productivity. The smaller the distance of timbers transportation, the higher the productivity and the lower the cost of production.

\subsection{Forest extraction planning for the rated project}

The total area presented 262.27 hectares (ha), being 256.30 ha of Eucalyptus plantations and 5.97 ha

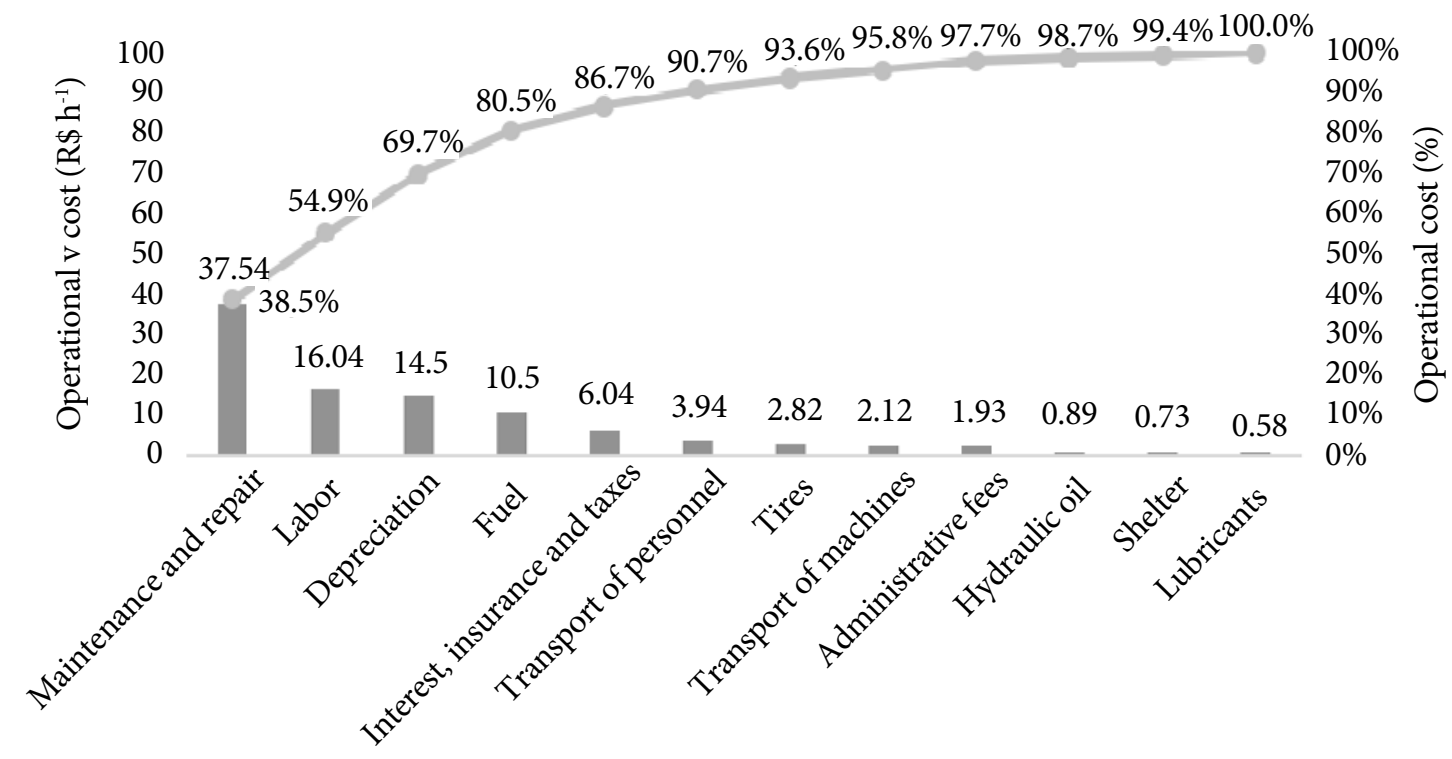

Figure 4. Operational cost of Ponsse Elephant forwarder. 


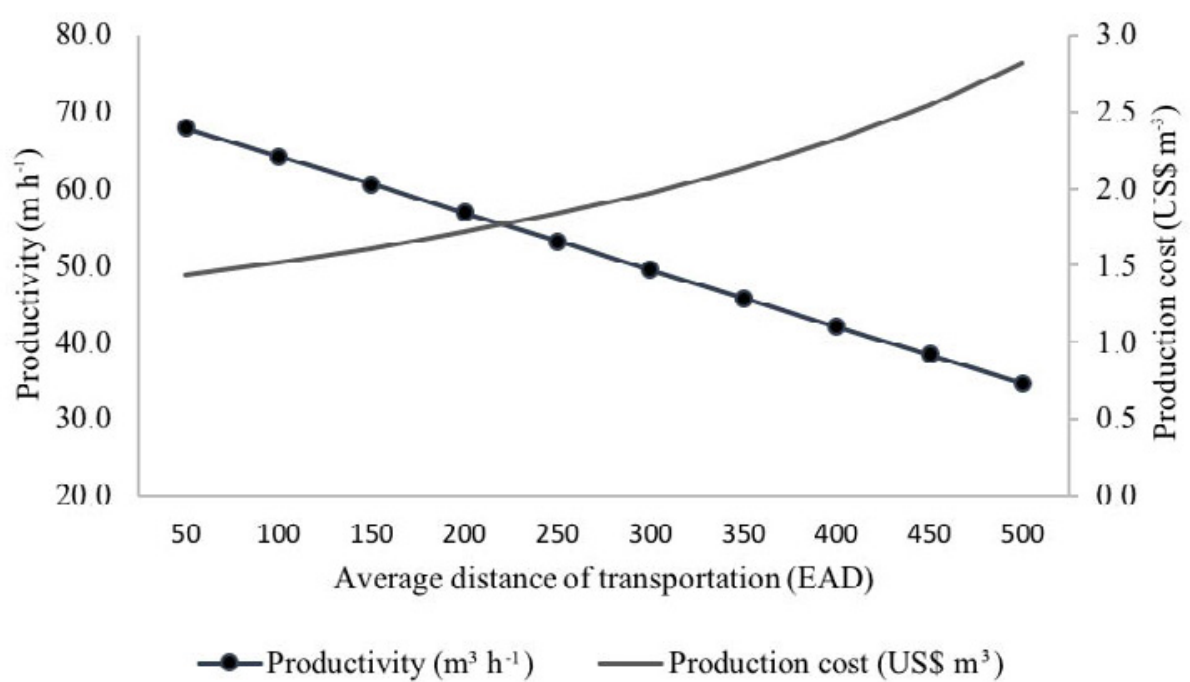

Figure 5. Productivity and production cost in function of average distance of transportation.

of road mesh, equivalent to 7,419 linear meters. Table 2 presents the result of planning in relation to quantification of the area of the plot, volume of wood to be extracted, average distance of transportation of timbers, forwarder productivity depending on the distance of timbers transportation (obtained by modeling), extraction cost per cubic meter. Figure 5 presents the map of the forest project with the sense of timbers transportation, cell formation sites, and identification of the forestry plots.

According to Table 2, illustrated in Figure 6, the project presented 10 plots with an average distance of timbers transportation ranging from $73.47 \mathrm{~m}$ to $191.85 \mathrm{~m}$, with extraction cost per cubic meter of US\$ 1.47 and US\$1.70, respectively. The increase of 118.38 meters in the extraction distance represented an impact of $15.64 \%$ on the forwarder cost. This

Table 2. Extraction cost of the forest project.

\begin{tabular}{|c|c|c|c|c|c|c|c|c|}
\hline Plot & $\begin{array}{c}\text { Area } \\
\text { (ha) }\end{array}$ & $\begin{array}{l}\text { Wood volume } \\
\left(\mathrm{m}^{3}\right)\end{array}$ & $\begin{array}{l}\text { MEAD } \\
(\mathrm{m})\end{array}$ & $\begin{array}{c}\text { EAD } \\
(\mathrm{m})\end{array}$ & $\begin{array}{l}\text { Productivity } \\
\left(\mathrm{m}^{3-1}\right)\end{array}$ & $\begin{array}{l}\text { Extraction cost } \\
\left(\mathrm{US} \$ \mathrm{~m}^{-3}\right)\end{array}$ & $\begin{array}{c}\text { Extraction cost } \\
\left(\text { US\$ ha } \mathbf{h}^{-1}\right)\end{array}$ & $\begin{array}{c}\text { CET } \\
\left(\text { US\$ } \mathbf{~ m}^{-3}\right)\end{array}$ \\
\hline 1 & 7.37 & $1,842.31$ & 251.49 & 125.75 & 62.33 & 1.57 & 391.41 & $2,885.57$ \\
\hline 2 & 8.70 & $2,173.12$ & 220.72 & 110.36 & 63.47 & 1.54 & 384.40 & $3,342.75$ \\
\hline 3 & 38.06 & $9,511.12$ & 383.69 & 191.85 & 57.45 & 1.70 & 424.70 & $16,163.76$ \\
\hline 4 & 45.39 & $11,342.79$ & 250.48 & 125.24 & 62.37 & 1.57 & 391.18 & $17,755.34$ \\
\hline 5 & 27.80 & $6,947.02$ & 275.64 & 137.82 & 61.44 & 1.59 & 397.10 & $11,039.01$ \\
\hline 6 & 42.32 & $10,574.70$ & 243.51 & 121.76 & 62.63 & 1.56 & 389.57 & $16,484.95$ \\
\hline 7 & 8.18 & $2,045.09$ & 146.94 & 73.47 & 66.20 & 1.47 & 368.57 & $3,016.24$ \\
\hline 8 & 4.30 & $1,075.40$ & 272.01 & 136.01 & 61.57 & 1.59 & 396.23 & $1,705.12$ \\
\hline${ }^{*} 9 \mathrm{a}$ & 35.80 & $8,945.82$ & 371.65 & 185.83 & 57.89 & 1.69 & 421.43 & $15,086.24$ \\
\hline$* 9 b$ & 14.01 & $3,501.90$ & 256.75 & 128.38 & 62.14 & 1.57 & 392.64 & $5,502.11$ \\
\hline 10 & 24.37 & $6,090.64$ & 261.09 & 130.55 & 61.98 & 1.58 & 393.65 & $9,594.24$ \\
\hline Total & 256.30 & $64,049.91$ & 286.19 & 143.09 & 61.05 & 1.60 & 400.21 & $102,575.33$ \\
\hline
\end{tabular}

MEAD: maximum extraction average distance; EAD: extraction average distance; CET: extraction cost (plot); ${ }^{*}$ weighted average depending on the size of the plot. The $9^{\text {th }}$ plot has been subdivided, passing to constitute two units of planning (plot $9 \mathrm{a}$ and plot $9 \mathrm{~b}$ ). 
result is explained by the increase in the time of the operational cycle, reducing the number of loads performed per effective hour and consequently increasing the production cost.

The Figure 6 illustrates the map of the evaluated project, being represented the 10 battalions with respective plans for the direction of wood extraction.

Seixas and Castro (2014) claim that the optimum extraction distance for systems of short logs using the forwarder is between $200 \mathrm{~m}$ and $300 \mathrm{~m}$ to achieve average productivity of $30 \mathrm{~m}^{3} \mathrm{~h}^{-1}$. In the evaluated project, the

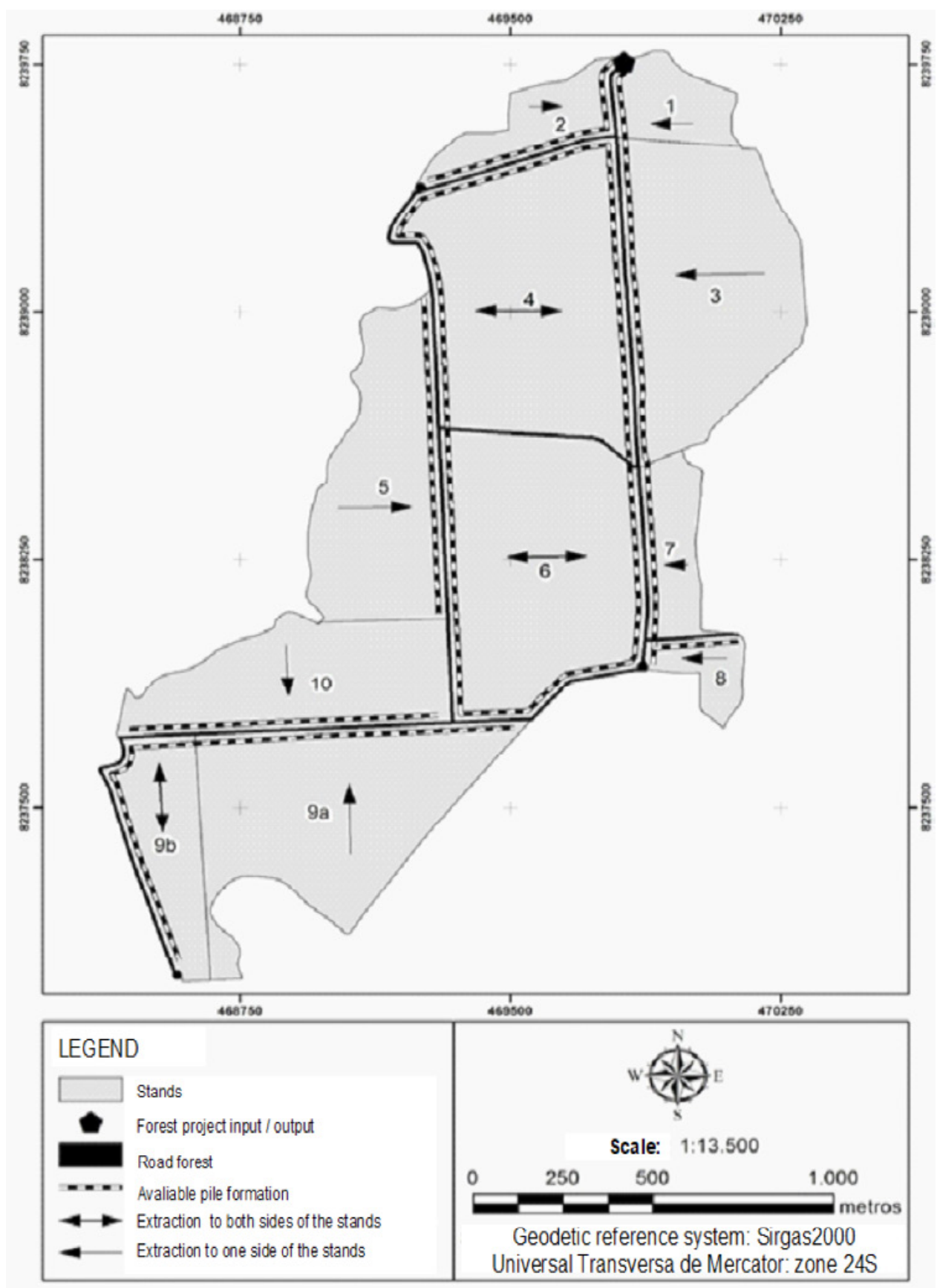

Figure 6. Map of the evaluated project. 
recommended by Seixas and Castro (2014) was not observed, all the plot presented EAD less than 200 meters, which justifies the high productivity of the equipment. Currently, many forest companies use of 125 meters, depending on the high productivity of equipment and consequent reduction of production costs.

Regarding the planning of the operation of forest extraction with the forwarder, several factors should be observed for improvement of productivity, in addition to the variable distance of timbers transportation.

According to Malinovski \& Malinovski (1998), productivity of a particular operation is in function of external variables (site characteristics) and machine variables (mainly the operational and the characteristics of the base machine and the operation implements). Lacerda et al. (2015) point out as influential factors in the forest extraction operations with the forwarder and the efficiency in maintenance processes (corrective or preventive) qualified professionals in the operation, efficient transportation of employees and machinery for production area.

As for the results presented in the research, they showed great importance in the aid to the forest harvest planning; thus, when analyzed together with other influential factors in the forest extraction process, they allow to estimate how much it will cost to harvest a project. In addition, it can assess the need to insert or remove forest roads.

The use of geotechnology as a planning tool can assist several stages of a forestry venture, from the acquisition of land to implementation of planting until harvest time; however, it is essential to accurate information collected so that the results estimated by geotechnology be trustworthy.

\section{CONCLUSIONS}

The use of geotechnology was important in the planning phase for determining the costs of the forest harvest, because through data obtained and in the processing of information georeferenced, it was possible to simulate the cost of the timber transportation for different extraction distances.

The proposed methodology and work allowed to estimate the extraction distance in the plots, this being a high-influence parameter in the forest extraction costs.
The technical modeling of productivity, depending on the distance of extraction, showed to be of great importance, mainly, regarding the distribution of the road mesh within the forest projects.

\section{ACKNOWLEDGEMENTS}

We are thankful for Universidade Estadual do Sudoeste da Bahia (Uesb) for supporting the research.

\section{SUBMISSION STATUS}

Received: 18 Aug., 2017

Accepted: 31 Aug., 2018

\section{CORRESPONDENCE TO}

\section{Luis Carlos de Freitas}

Universidade Estadual do Sudoeste da Bahia (Uesb), Departamento de Fitotecnia e Zootecnia, Estrada do Bem Querer, km 4, CEP 45031-900, Vitória da Conquista, BA, Brasil e-mail: luisfreitas@uesb.edu.br

\section{REFERENCES}

American Society of Agricultural Engineers - Asae. Asae standards 2001: machinery, equipment and buildings: operating costs. Ames; 2001.

Conaw PL. Estatística. São Paulo: Edgard Blucher; 1977.

Empresa Brasileira de Pesquisa Agropecuária - Embrapa. Sistema brasileiro de classificação de solos. Rio de Janeiro: Embrapa Solos; 2006.

Koeppen W. Climatologia: con un estudio de los climas de la tierra. México: Fondo de Cultura Económica; 1948.

Lacerda LC, Fiedler NC, Chichorro JF, Carmo FCA, Mendonça AR. Análise operacional da extração florestal mecanizada em módulos próprios e terceirizados. Revista Nativa 2015;3(3): 205-209. 10.14583/2318-7670.v03n03a10

Leite ES, Fernandes HC, Minette LJ, Souza AP, Leite HG, Guedes IL. Modelagem do desempenho da extração de madeira pelo "forwarder". Revista Árvore 2014; 38(5): 879-887. 10.1590/S0100-67622014000500012

Lopes ES, Rodrigues CK, Carmo FC, Fiedler NC, Oliveira D. Avaliação técnica e de custos de um sistema de cabos aéreos na extração de Pinus taeda L. em região montanhosa. Scientia Forestalis 2011 [cited 2019 May 27]; 39(91): 387-394. Available from: https://bit.ly/2wu9YjH 
Machado CC, Silva EM, Pereira RS, Castro GP. O setor florestal brasileiro e a colheita florestal. In: Machado CC, editor. Colheita florestal. Viçosa: UFV; 2014. p. 15-45.

Malinovski RA, Malinovski JR. Evolução dos sistemas de colheita de madeira para pinus na região Sul do Brasil. Curitiba: FUPEF; 1998.

Malinovski RA, Malinovski RA, Malinovski JR, Yamaji FM. Análise das variáveis de influência na produtividade das máquinas de colheita de madeira em função das características físicas do terreno, do povoamento e do planejamento operacional florestal. Floresta 2006; 36(2): 169-182. 10.5380/rf.v36i2.6459

Mazão C, Brown RO, Robert RCG. Análise da produtividade de um forwarder com o aumento da área da garra de carregamento. Espacios 2017 [cited 2019 May 27]; 38(11): 20-27. Available from: https://bit.ly/30FkFxQ

Minette LJ, Moreira FMT, Souza AP, Machado CC, Silva KR. Análise técnica e econômica do forwarder em três subsistemas de colheita de florestas de eucalipto. Revista Árvore 2004; 28(1): 91-97. 10.1590/S0100-67622004000100012

Minette LJ, Silva EN, Miranda GM, Souza AP, Fiedler NC. Avaliação técnica da operação de extração de Eucalyptus spp. utilizando o trator auto carregável e o trator florestal transportador "forwarder" na região sul da Bahia. Engenharia na Agricultura 2008 [cited 2019 May 27]; 16(3): 312-317. Available from: https://bit.ly/2Wa5q1t
Moreira FMT, Souza, AP, Machado CC, Minette LJ, Silva KR. Avaliação operacional e econômica do "fellerbuncher" em dois subsistemas de colheita de florestas de eucalipto. Revista Árvore 2004; 28(2): 199-205. 10.1590/ S0100-67622004000200006

Novaes AB, São José AR. Caracterização da região da mata de cipó no sudeste da Bahia. In: Novaes AB, São José AR, Barbosa AA, Souza IVB. Reflorestamento no Brasil. Vitória da Conquista: UESB; 1992. p. 7-16.

Ponsse. Forwarder elephant. 2014 [cited 2017 Jul. 23]. Available from: https://bit.ly/2O1chqr

Seixas F, Castro GP. Extração. In: Machado CC, editor Colheita florestal. Viçosa: UFV; 2014. p. 106-157.

Silva ML, Miranda GM, Cordeiro AS, Leite ES. Custos. In: Machado CC, editor. Colheita florestal. Viçosa: UFV; 2014. p. 253-285.

Simões D, Fenner PT. Avaliação técnica e econômica do forwarder na extração de madeira em povoamento de eucalipto de primeiro corte. Floresta 2010; 40(4): 711-720. 10.5380/rf.v40i4.20323

Spatial Ecology. Hawth's analysis tools for ArcGIS. 2007 [cited 2016 Dec. 5]. Available from: https://bit.ly/2I5s690

Spinelli R, Ward SM, Owende PM. A harvest and transport cost model for Eucalyptus spp. fast-growing short rotation plantations. Biomass and Bioenergy 2009, 33(9): 1265-1270. 10.1016/j.biombioe.2009.05.010 